\title{
Are Wealthy Economies Expected to Have Better Accounting Quality? Hypothesis Development
}

\author{
Erekle Pirveli, PhD \\ Associate Professor \\ Caucasus School of Business \\ Caucasus University \\ Georgia \\ Nikoloz Koiava, PhD \\ Associate Professor \\ Business School \\ Ilia State University \\ Georgia \\ Daviti Petriashvili, MSc \\ PhD Student \\ Tbilisi State University \\ Georgia
}

Faculty of Economics and Business Administration,

\begin{abstract}
The purpose of this paper is to develop a pertinent hypothesis whether wealthy economies are likely to have better accounting quality compared to their poor counterparts. Prior literature has suggested that wealthy economies are expected to invest more in the establishment and development of the country-level financial reporting infrastructures such as financial, legal and political systems, which should ultimately lead to better accounting quality. This paper argues that while examining the relation between country wealth and accounting quality, it is important to distinguish between controlling-useful and valuation-useful accounting information. Namely, this paper expects wealthy economies to have more controlling-useful-, but not necessarily more valuation-useful accounting information. For wealthy economies, the authors expect the reporting environments where decision makers feel legally and politically secured, but where not a particularly strong demand on accounting information is stemmed from the capital markets as opposed to banks. While so, we further acknowledge that capital markets participants require more valuation-useful and the banking sector participants more controllinguseful accounting information. To our best knowledge, it is the first paper that argues that the link between country wealth and accounting quality should be positive regarding controlling-useful accounting information but is unclear regarding valuation-useful accounting information. The formulated hypothesis opens the way to future empirical research in the field.
\end{abstract}

Keywords: Accounting quality, Earnings quality, Country wealth, Country-level financial reporting infrastructure, Controlling-useful accounting information, Valuation-useful accounting information

\section{Introduction}

This paper provides a theoretical foundation whether wealthy economies are likely to have better accounting quality (AQ) compared to their poor counterparts. Prior literature has examined international financial reporting practices in the light of country-level reporting determinants and has suggested that AQ tends to be higher in economies with strong financial, legal and political systems (Watts and Zimmerman, 1986, Teoh et al., 1998a, Ball et al., 2000, Leuz et al., 2003). Most of the existing international studies on AQ centers upon country-group comparisons - comparing market-based economies to the bank-based ones; common-law legal origin countries to the code-law ones; and countries following international financial reporting standards to the ones with local financial reporting standards. 
The existing literature helps us to understand the reasons of international AQ differences based on country-group comparisons (that is to compare a set of countries against another set of countries) but fail to address these differences in a pooled sample, without country-grouping (e.g., Leuz et al., 2003). Country-group differences in international AQ can be driven by a single strong player within the group, which outweighs the whole group's performance (Ball et al., 2000). As such, despite of the existing valuable scholarly efforts, the field is still unclear of what drives the existing international differences in AQ at a country-level. A general expectation in the field is that country wealth would explain the existing differences in international AQ.

It has been assumed that wealthy economies invest more in the establishment and development of country-level financial reporting infrastructures - financial, legal and political systems -, which should ultimately lead to better AQ (Ball, 2016). This paper argues that while examining the relation between country wealth and AQ, it is important to segregate between the two objectives of financial reporting: controlling-usefulness and valuationusefulness. Following the Revised Conceptual Framework of FASB (2010), this paper defines a) controllingusefulness of accounting information as the power of this information to help insiders/shareholders in assessing management's actions - how to remunerate them, whether to replace or reappoint them, and how to vote on shareholder proposals about management's policies and $b$ ) valuation-usefulness of accounting information as the power of accounting information to help equity investors in predicting the stock prices (company value). Controlling-useful accounting numbers help us to understand how 'good' the past year has been and based on this information plans the upcoming performance, while valuation-useful accounting numbers center on future aiming to predict future stock prices (company value) (Ball and Brown, 1968, Basu, 1997, Gassen, 2008).

We argue that country wealth - as an indication of a country's level of affordability to buy and develop highquality reporting infrastructures - should be significantly linked to better legal and political-, but not necessarily to a financial system. Financial system strength should rather be an outcome of a large pools of investors' joint efforts, not merely conditioned by a certain government's good will. Overall, for wealthy economies, this paper expects the reporting environments where legal and political systems are efficient but financial systems do not necessarily function based on capital markets as opposed to banks. Moreover, because of the fiercer competition and more advanced trading technologies at a place, the diversity and intensity of the use of alternative channels of information is likely to be higher within the wealthy economies. This, again, heightens the likelihood that investors base their investment decisions on all possible sources of information, which lowers demand for valuation-useful accounting numbers within the wealthy economies.

While legal and political systems promote demand both for controlling- and valuation-useful accounting information, examination of AQ for capital market listed firms would put a higher importance on the strength of a financial system as a driver of AQ. Building on this point, we then refer to the theory of financial intermediation. Scholes et al. (1976) suggest that within capital market-based economies, a higher importance is given to valuation-useful accounting information, while the debt-based economies mainly appreciate the controlling-useful accounting numbers (also see: Ball et al., 2008, Gassen, 2008). Given this, and the abovementioned scenario that for wealthy economies better legal and political, but not necessarily more capital market-based financial systems are expected, we predict higher demand for a controlling-useful, but not necessarily for a valuation-useful accounting data within the wealthy economies.

This study contributes to a large body of existing literature on international differences in AQ (Alford et al., 1993, Jacobson and Aaker, 1993, Pope and Walker, 1999, Ball et al., 2000, Leuz et al., 2003, Barth et al., 2008). To the authors' best knowledge, this is the first study that theoretically argues that country wealth cannot explain the international differences in AQ concerning both objectives of financial accounting: controlling-usefulness and valuation-usefulness. The formulated hypothesis opens the way to future empirical research in accounting that should test whether the formulated expectation holds in practice. The next section reviews the existing literature, explores the research gap and develops a hypothesis. The final part concludes.

\section{Literature Review}

Accounting Quality (AQ) has been studied throughout the decades as it attains a particular interest of accounting information supply chain participants. This interest is not surprising as AQ shows the extent to which accounting system serves its primary function - to help accounting information users in decision making (FASB, 1980; 2016). 
Since the 1970s, prior literature has looked at both time-series and cross-sectional analysis of AQ (Ball and Brown, 1968, Beaver, 1968, Ball and Watts, 1972, Collins and Kothari, 1989, Dechow et al., 1995, Ball et al., 2000, Barth et al., 2001, Leuz et al., 2003, Dechow et al., 2010). Compared to time-series analysis, cross-sectional studies have emerged with a relative resistance. Not only data availability limitations for many (especially for underdeveloped) economies caused such a resistance, but also the common acknowledgment that a cross-country variation in institutional factors could lead to biased statistical outcomes, has also contributed to such a time lag. Recently, the volume of international studies has been considerably increasing. The rate of globalization - as the politics and business become more connected - is one of the drivers of this process (Ball, 2016). In addition, increasing data availability in data-readable machines facilitates researchers to base their analyses on larger samples, also covering many of the underdeveloped economies (Kothari, 2001). Moreover, now the field is aware that institutional diversity and complexity across countries provides not merely difficulties but also huge opportunities for a research. Conduction of comparative analysis within international studies, enables us to learn the effects of country-level determinants on the international reporting practices. As Ball (2016) notes: "[...] we live at a high point in international accounting research."

Alford et al. (1993) is one of the first studies that examines AQ internationally. The early studies merely catalogue the existing international differences in AQ, without testing a hypothesis (Alford et al., 1993, Jacobson and Aaker, 1993). Later literature, by delving deeper into AQ determinants, aimed to gauge the causal factors of the existing international differences in the reporting practices. Three large streams of the cross-country AQ determinants literature can be distinguished. AQ is expected to be higher in economies with strong a) financial, b) legal and c) political systems. While the links between these three systems and AQ are tightly introduced as next, for a broad literature review on the country-level determinants of AQ, see Ali and Hwang (2000), Soderstrom and Sun (2007) and Pirveli (2015).

\subsection{Financial System's Influence on AQ}

The influence of financial system on AQ is channeled through the demand on accounting information. The discussions concentrate on the levels of capital market development separately as well as in conjunction to the banking sector development. Accounting information consumers (investors, creditors and other decision makers) rely on accounting information in investment/crediting decisions and thereby shape a demand for informative financial statements. The larger the pools of interested investors at a stock exchange, the higher the demand for informative financial statements. Given this scenario, it might then be expected that market pressures will entice managers to actively prepare high quality reports, subject of high incorporation in investment decisions (Teoh et al., 1998a, Teoh et al., 1998b, Burgstahler et al., 2006).

A critical turnover here is that from accounting's perspective, a strong financial system stands for a capitalmarket-, rather than for a debt-based financial system (Soderstrom and Sun, 2007, Ball et al., 2008). As opposed to debt-based economies, scholars expect corporate insiders in market-based economies to be more interested in disclosing high-quality accounting information. Intensive demand, typical in the capital market-based economies, incentivizes insiders to pay added attention to the production and dissemination of highly representative information. This is because in market-oriented systems investors have a limited access to the internal/private information. In the absence of private channels, investors rely heavily on publicly available information (financial statements) while valuing securities. Banks, as primary agents in bank-based systems, prefer to base their crediting decisions on the offered real guarantees (e.g., collateral) rather than on the balance sheets (Dechow and Schrand, 2004, Ball and Shivakumar, 2005, Goncharov and Zimmermann, 2007, Ball et al., 2008). Banks not only have to forecast the chances of loan return but must also qualify in customers' private habits through intensive conversations to draw a clear picture of the potential outcomes. This requires the evaluation of risk, liquidity, debt capacity, and the amount of collateral potential borrowers have at their disposal. The accessibility of these more convenient and secured instruments enables banking institutions to rely less on financial statements while assessing creditor solvency (Schumpeter, 1939, Abu-Nassar and Rutherford, 1996, Bushman and Piotroski, 2006, Chen et al., 2011).

\subsection{Legal System's Influence on AQ.}

Discussions on the influence of a legal system on AQ cover a) legal origin, b) investor protection and c) legal enforcement. a) Company law and the law on securities market together with the accounting and auditing standards explicitly regulate the reporting practices (Goshen, 2003, Goshen and Parchomovsky, 2005, Davies, 2010, Zimmermann and Werner, 2013). 
Standard setters are influenced by various accounting information consumers (e.g., managers, shareholders, banks, tax authorities, labor unions) in the standard setting process. While the demand for high-quality accounting rules is driven by investors, accounting standards are set by professional organizations under varying degrees of governmental intervention (Watts and Zimmerman, 1978, Watts and Zimmerman, 1986, La Porta et al., 1997, La Porta et al., 2000). Such a governmental intervention in standard and law formulation processes increases the likelihood that the regulations will appear as a more authority-oriented framework (Choi and Mueller, 1992). The higher the extent of authorities' involvement in the development and interpretation of accounting standards, the less room professional accounting bodies have in contributing to the overall process (Watts and Zimmerman, 1986, La Porta et al., 2000). Governmental interests may focus, quite naturally, on overall budget concerns reflected in tax system-, or national and/or macroeconomic policy adjustments.

In contrast, professional organizations are likely to seek to address the needs of capital providers, thereby increasing the availability of efficacious accounting information (Soderstrom and Sun, 2007). Consequently, higher AQ is expected in countries where governmental intervention and interaction in the standard/law formulation process is limited (Choi and Mueller, 1992, Wyatt, 1997, Oehr and Zimmermann, 2012). While so, the extent to which government bodies take part in the standard/law setting process is strongly correlated to the origins of a country's legal system. Using commercial codes to differentiate states, researchers have created typological profiles of countries, focusing on their most central characteristics. Based on these characteristics two major groups are: common- and civil-law legal origin countries (La Porta et al., 1998, Merryman and PérezPerdomo, 2007, Oehr and Zimmermann, 2012).

b) Capital markets cannot be well-developed without a strong legal system, promoting investor safety (Black, 2001). Investors tend to invest in those capital markets where high-quality investor rights are established. Robust legal systems, by ensuring the availability of reliable accounting information, protect investors against abuse from corporate insiders and, overall, promote an investor-friendly environment. Appropriatelyfunctioning legal systems provide the environment in which investor rights are allowed to grow and solidify, which in turn leads to system's stability (Shleifer and Vishny, 1997, La Porta et al., 2000). Such security in investor rights not only underpins the stability of legal systems, but they also motivate the choice and structuring of firm policy choices. Strong investor protection is a pivotal pillar in the determination of AQ, as it affects the extent of stock market development and ownership structures (Ali and Hwang, 2000, Leuz et al., 2003). In the absence of proper investor rights, the law does not ensure investor indemnification, thereby diminishing the extent of capital investment and promoting a more concentrated ownership structure. In such situations, companies face significant barriers to securing external funding sources. As opposed to this, appropriately formulated investor rights limit the ability of corporate managers to manipulate financial outcomes and guard investors against victimization, suggesting a positive correlation between investor protection and AQ.

c) Formulation of high-quality legal laws is of utmost importance. High-quality legal frameworks are rational only if they are adequately instituted in practice. The importance of regulations retrogrades if these rules are not appropriately adhered to by parties. A certain law might be of high quality, promoting transparent reporting and high AQ. However, if the law is not adequately enforced, the importance of its quality might be effectively nullified. Therefore, legal enforcement, the extent at which companies are pressured to comply with the dictated regulations, should be anticipated by parties to ensure compliance (La Porta et al., 1998, Zimmermann and Werner, 2013). Legal enforcement activities may manifest themselves in a variety of manners. Changes may take place in courts (regulatory and legal changes), at stock exchanges, and in the attitudes of financial statement preparers and external auditors. Countries with robust enforcement mechanisms can implement efficient sanction systems. Efficient sanction systems, in turn, promote the compliance of firms by instituting reasonable fines against non-compliers.

\subsection{Political System's Influence on AQ.}

Political system covers a) corruption levels, b) informal government interventions and c) tax policies.

a) Politicians in highly corrupted environment attempt to optimize their own profits by legal and illegal activities. Aware of politicians who are bribe-seekers, managers become incentivized to manage earnings for their own benefits. That is, such managers seek out preferential treatment from such amenable authorities regarding cheap credits, low taxes, monopoly status, and/or order purchasing. Consequently, managers are prone to offer bribes to government representatives and conceal damaging operations/transactions from reporting. 
To obscure illegal operations from financial statements, corporate managers either remove the non-desirable balance sheet items entirely or strategically and discretely bury the undesirable information. Consequently, firms operating in highly corrupted countries (compared to uncorrupted countries), experience lower AQ (Chaney et al., 2011).

b) Intensive government involvement in the business sector manifests itself in high operating risk and weakened property rights which promotes to concentrated ownership structures (Watts and Zimmerman, 1986). Additionally, increased risk of government expropriation creates an ambiguous operating environment. To avoid redundant attention and monitoring from authorities, firms are prone to avoid substantially abnormal (too high or too low) earnings. This is because drastically high incomes may signal for a monopolistic threat for consumers and drastically low incomes may well indicate on potential bankruptcy. In countries, where politicians are interested, and able, to supplement governmental budgets or their personal finances by expropriating the assets of prosperous companies, managers appear under considerable pressure to camouflage financial numbers within the statements (Bushman and Piotroski, 2006).

c) The higher the tax-burden in general and the income tax in particular, the greater the tax policy's influence on AQ. High tax-burdens promote taxation strategies to offset the importance of stock market purposes. If tax purposes preponderate over the market incentives, financial accounting numbers are adjusted to tax-accounting figures rather than the reverse. This is because, firms, in addition to financial accounting, also prepare tax accounting statements. Financial accounting serves for capital market interests and tax accounting are intended for tax authorities. Capital markets appreciate current and practical accounting information for decision-making, whereas tax authorities focus on an equitable revenue collection and may even penalize for overly conservative tax reporting (Ball et al., 2000, Desai, 2005). Firms might be interested in disclosing over-estimated information to meet certain capital market goals (target beating; obtaining high share prices before IPO; etc.) and underestimated information to minimize income taxes (Dechow and Schrand, 2004). Addressing all parties' needs may signal manipulation and attract undesirable attention from outsiders' (e.g., regulators). Such competing interest mediation may ultimately be reflected in increased political costs, especially in countries with intensive state interventions in the business sector. Overall, in countries with pervasive corruption, ubiquitous political connections, recurrent informal governmental interventions and high tax burden, corporate managers tend towards more questionable and less transparent financial reporting.

\section{Research Gap}

While revealing country-level determinants of $\mathrm{AQ}$, most of the prior literature has disentangled two (or more) sets of country groups. Usually, countries are classified by a dichotomous variable - e.g., putting 1 forcapital marketbased economies and 0 for the debt-based ones; 1 for common-law legal origin countries and 0 for the code-law ones (La Porta et al., 1997, Ball et al., 2000, Leuz et al., 2003, Ball et al., 2008). These studies help us to understand the reasons of international AQ differences based on the country-groups but fail to address these differences on a country-based perspective. Comparisons across country clusters do not allow us to reveal a precise picture on the drivers of AQ across the nations. Group differences could be driven by a one (or several) strong player(s) within the group, which drives the whole group's performance.

While very prevalent decades ago, common-law and code-law legal origin segregation of countries does not help us to draw a holistic picture on the existing international differences in AQ. A dichotomous separation of countries, say by the legal origin, is assumed to proxy for the legal and political influence on the standard setting and enforcement processes. This proxy appears as a weak summary measure of such influence because of the existing overlaps between the common-law and code-law institutions (Ball et al., 2000). Even between the common- or code-law countries, it cannot be judged that the influence of political processes is identical. While so, these differences are neglected by assigning each country within the same group with the same measurement (either 1 or 0 ). Many countries might have been named common-law countries at one time but might have change their trends along the years; many countries following British-American accounting rules in the past, exhibit reduced demand for accounting information today. For example, empirical evidence suggests that even though Singapore and Hong Kong have common-law legal origins, their reporting practices do not actually reveal financial reporting fundamentals similar to other common-law legal origin countries such as the USA or Australia (Ball et al., 2000, Ball et al., 2008). As such, despite of the existing valuable scholarly efforts, the field is still unclear of what drives country-level differences in AQ across the nations. Why is AQ at a certain level in Singapore and at a dramatically different extent in the USA? What causes these differences? 


\section{Hypothesis Development}

Country wealth has been presumed to be a factor that positively links to country-level financial reporting infrastructures (financial, legal and political systems) and reflects into better AQ. For example, according to Ball (2016, p. 8): "There are substantial regime-level costs of developing and operating an effective reporting infrastructure, including securities laws, accounting rules, an independent and effective judiciary, an independent and effective audit profession, professional education, regulatory functions, and sundry monitoring institutions (analysts, rating agencies, press, etc.). [...] richer economies tend to build a high-quality financial reporting infrastructure. [...] poorer countries cannot be expected to have made the same level of investment in the infrastructure required to achieve high quality reporting."

It is argued that accounting information, as a costly economic good that reflects the devoted resources on this information, should be an increasing function of country wealth. While this expectation seems highly intuitive and logical, it is a subject of empiricism to prove such an association. Merely to bring the examples of Japan (a wealthy country commonly experiencing low AQ) and Singapore (again a wealthy country with top reporting infrastructures but commonly experiencing a low AQ) (see: Ball et al., 2003, Leuz et al., 2003) may already put the intuitively suggested positive link between country wealth and AQ under a suspicion. Moreover, by delving deeper to the topic, this paper theoretically challenges the existing expectation and witnesses some new insights. This paper argues that while examining the relation between country wealth and AQ, it is vital to distinguish between controlling-useful and valuation-useful accounting information. Country wealth hints on a government's level of affordability to buy and develop necessary country-level reporting infrastructures (Smith and McCulloch, 1838, Ball, 2016). While so, purchase and development of different financial reporting infrastructures (systems) should necessitate different levels and portions of government's affordability. For example, to develop a healthy financial system where capital markets' role is significant (as opposed to banks) in formulating demand on accounting information, apart from a government's good will, market participants' role would be decisive. This is because market demand on accounting information is stemmed by a large number of market actors, rather than by a single (even though a strong) player such as a government. In contrast, a government's good will and the consequent government spending should be a more dominant (and presumably enough) factor to build efficient legal and political systems, where investors, creditors and other decision makers feel secured. In other words, the forces necessary to develop healthy financial systems on the one hand, and legal and political systems on the other, would imply different portions of governments' and market participants' efforts. Based on this, this paper expects country wealth to be a more influential factor in building efficient legal and political systems, than in building a strong financial system. Thus, for wealthy economies this paper expects the reporting environments where legal and political systems are efficient, but financial systems do not necessarily function based on capital markets as opposed to banks.

Legal and political systems serve to address conflicts between insiders and outsiders, promoting investor safety, their attraction to capital markets and therefore a strong demand on accounting information. This would imply a strong demand both for controlling- and valuation-useful accounting information. However, while examining AQ for capital market listed firms, it is likely that financial system would play a particularly high role in shaping the accounting numbers' fitness. Accounting literature states that capital market actors appraise more valuation-useful financial reports and the banking sector representatives value the importance of controlling-useful accounting information (Soderstrom and Sun, 2007, Ball et al., 2008). According to the theory of financial intermediation, demand for controlling-useful accounting information is expected to be higher in debt-based economies as debt holders typically face higher transaction costs compared to equity holders (Scholes et al., 1976). Consequently, in the settings where debt decisions supersede capital market decisions, this paper expects a higher demand on a controlling-useful accounting information - because of closer shareholder-manager contacts, accounting incomes to be quickly incorporated into financial statements. Agents in such an environment are likely to be closely contracting with firms, and accounting income is likely to be a pie that is divided among groups as dividends to shareholders, bonuses to managers and employees, and taxes to governments. The demand for accounting income is likely to be conditioned by the payout preferences rather than by the public disclosure. On contrary, as within the wealthy economies capital market actors are not dominant financial system players, a moderate demand is expected on a valuation-useful accounting information that would yield proper estimations of the future cash flows. 
Country wealth is likely to also hint on the existence of high quality trading and information processing infrastructures at the local capital markets (Campbell et al., 1997, Saunders and Thomas, 1997, Alfaro et al., 2004). The diversity and intensity of the use of alternative sources of information might be higher within the wealthy economies. This is because at such economies the competition is fierce, the demand is strong and investors attempt to base their decisions on all possible sources of information, not merely looking on often times "delayed" financial statements (Lev, 1983, Collins et al., 1997, Francis and Schipper, 1999, Lev and Zarowin, 1999, Core et al., 2003, Kothari and Shanken, 2003, Balachandran and Mohanram, 2011, Lev and Gu, 2016). If country wealth would indicate on a more intensive utilization of other sources of information (analyst forecasts, technical/algorithm-based analysis, press releases and conference calls), this will imply a lower demand on valuation-useful accounting information.

Based on these argumentations, this paper hypothesizes:

H: Wealthy economies are likely to report more controlling-useful but not necessarily more valuationuseful accounting information compared to their poor counterparts.

\section{Conclusion}

This paper provides a theoretical background whether wealthy economies are expected to have better accounting quality compared to their poor counterparts. This paper argues that while examining the relation between country wealth and accounting quality, there is a need to distinguish between contracting-useful and valuation-useful accounting information. We expect wealthy economies to have more controlling-useful accounting information, but not necessarily more valuation-useful one. This is because country wealth is expected to be positively linked to better legal and political systems, but not necessarily to a better financial system. Financial system's efficiency is likely to be a decisive factor in driving the AQ of capital market listed firms. Not necessarily capital-marketoriented (as opposed to bank-oriented) financial systems within the wealthy economies, would imply a higher demand for controlling-useful but not necessarily for valuation-useful accounting information. This paper contributes to the existing literature on international differences in accounting quality. To the authors' best knowledge, this is one of the first studies that argues that it is unclear whether country wealth can explain the existing international differences in accounting quality as regards to both controlling-useful and valuation-useful accounting information. A promising future research field would be to empirically test whether herein formulated hypothesis holds in practice.

The authors appreciate the feedback from S. P. Kothari, Jochen Zimmermann, Giorgi Khishtovani, Ross L. Watts, George Rickmann, Wayne Landsman, Shivaram Rajgopal, Ken Peasnell, and workshop participants at the: American Accounting Association's annual meeting in Chicago (2015), WEI conference at Harvard Faculty Club (2016), MBAcademy conference in Barcelona (2017) and Accounting Seminar at the Caucasus University (2017). This research was supported by Shota Rustaveli National Science Foundation (SRNSF) [grant number YS15_2.5.2].

\section{References}

ABU-NASSAR, M. \& RUTHERFORD, B. A. (1996). "External users of financial reports in less developed countries: The case of Jordan". The British Accounting Review, 28, 73-87.

ALFARO, L., CHANDA, A., KALEMLI-OZCAN, S. \& SAYEK, S. (2004). "FDI and economic growth: the role of local financial markets". Journal of international economics, 64, 89-112.

ALFORD, A., JONES, J., LEFTWICH, R. \& ZMIJEWSKI, M. (1993). "The relative informativeness of accounting disclosures in different countries". Journal of Accounting Research, 183-223.

ALI, A. \& HWANG, L.-S. (2000). "Country-specific factors related to financial reporting and the value relevance of accounting data". Journal of accounting research, 38, 1-21.

ASHBAUGH, H. \& PINCUS, M. (2001). "Domestic accounting standards, international accounting standards, and the predictability of earnings". Journal of accounting research, 39, 417-434.

BALACHANDRAN, S. \& MOHANRAM, P. (2011). "Is the decline in the value relevance of accounting driven by increased conservatism?". Review of Accounting Studies, 16, 272-301.

BALL, R. (2016). "Why We Do International Accounting Research". Journal of International Accounting Research, 15, 1-6. 
BALL, R. \& BROWN, P. (1968). "An empirical evaluation of accounting income numbers". Journal of accounting research, 159-178.

BALL, R., KOTHARI, S. \& ROBIN, A. (2000). "The effect of international institutional factors on properties of accounting earnings". Journal of accounting and economics, 29, 1-51.

BALL, R., ROBIN, A. \& SADKA, G. (2008). "Is financial reporting shaped by equity markets or by debt markets? An international study of timeliness and conservatism". Review of accounting studies, 13, 168-205.

BALL, R., ROBIN, A. \& WU, J. S. (2003). "Incentives versus standards: properties of accounting income in four East Asian countries". Journal of accounting and economics, 36, 235-270.

BALL, R. \& SHIVAKUMAR, L. (2005). "Earnings quality in UK private firms: comparative loss recognition timeliness". Journal of accounting and economics, 39, 83-128.

BALL, R. \& WATTS, R. (1972). "Some time series properties of accounting income". The Journal of Finance, 27, 663-681.

BARTH, M. E., BEAVER, W. H. \& LANDSMAN, W. R. (2001). "The relevance of the value relevance literature for financial accounting standard setting: another view". Journal of accounting and economics, 31, 77-104.

BARTH, M. E., LANDSMAN, W. R. \& LANG, M. H. (2008). "International accounting standards and accounting quality". Journal of accounting research, 46, 467-498.

BASU, S. (1997). "The conservatism principle and the asymmetric timeliness of earnings1". Journal of accounting and economics, 24, 3-37.

BEAVER, W. H. (1968). "The information content of annual earnings announcements". Journal of accounting research, 67-92.

BLACK, B. (2001). "The legal and institutional preconditions for strong securities markets". As published in UCLA Law Review, 48, 781-855.

BOARD, F. A. S. (1980). "Statement of financial accounting concepts No. 2: qualitative characteristics of accounting information".

BOARD, F. A. S. 2006. Conceptual Framework for Financial Reporting: Objective of Financial Reporting and Qualitative Characteristics of Decision-Useful Financial Reporting Information.

BOARD, F. A. S. 2010. Conceptual Framework for Financial Reporting: Chapter 1, The Objective of General Purpose Financial Reporting, and Chapter 3, Qualitative Characteristics of Useful Financial Information.

BURGSTAHLER, D. C., HAIL, L. \& LEUZ, C. (2006). "The importance of reporting incentives: Earnings management in European private and public firms". The accounting review, 81, 983-1016.

BUSHMAN, R. M. \& PIOTROSKI, J. D. (2006). "Financial reporting incentives for conservative accounting: The influence of legal and political institutions". Journal of Accounting and Economics, 42, 107-148.

CAHAN, S. F., EMANUEL, D. \& SUN, J. (2009). "The effect of earnings quality and country-level institutions on the value relevance of earnings". Review of Quantitative Finance and Accounting, 33, 371.

CAMPBELL, J. Y., LO, A. W.-C. \& MACKINLAY, A. C. (1997). The econometrics of financial markets, Princeton University press Princeton, NJ.

CHANEY, P. K., FACCIO, M. \& PARSLEY, D. (2011). "The quality of accounting information in politically connected firms". Journal of Accounting and Economics, 51, 58-76.

CHEN, F., HOPE, O.-K., LI, Q. \& WANG, X. (2011). "Financial reporting quality and investment efficiency of private firms in emerging markets". The accounting review, 86, 1255-1288.

CHOI, F. D. S. \& MUELLER, G. G. (1992). International Accounting, Prentice-Hall. New Jersey.

COLLINS, D. W. \& KOTHARI, S. (1989). "An analysis of intertemporal and cross-sectional determinants of earnings response coefficients". Journal of accounting and economics, 11, 143-181.

COLLINS, D. W., MAYDEW, E. L. \& WEISS, I. S. (1997). "Changes in the value-relevance of earnings and book values over the past forty years". Journal of accounting and economics, 24, 39-67.

CORE, J. E., GUAY, W. R. \& VAN BUSKIRK, A. (2003). "Market valuations in the new economy: An investigation of what has changed". Journal of Accounting and Economics, 34, 43-67.

DASKE, H. \& GEBHARDT, G. (2006). "International financial reporting standards and experts' perceptions of disclosure quality". Abacus, 42, 461-498.

DASKE, H., HAIL, L., LEUZ, C. \& VERDI, R. (2008). "Mandatory IFRS reporting around the world: Early evidence on the economic consequences". Journal of accounting research, 46, 1085-1142.

DAVIES, P. L. (2010). Introduction to company law, Oxford University Press. 
DECHOW, P., GE, W. \& SCHRAND, C. (2010). "Understanding earnings quality: A review of the proxies, their determinants and their consequences". Journal of accounting and economics, 50, 344-401.

DECHOW, P. M. \& SCHRAND, C. M. (2004). "Earnings quality".

DECHOW, P. M., SLOAN, R. G. \& SWEENEY, A. P. (1995). "Detecting earnings management". Accounting review, 193-225.

DEFOND, M., HUNG, M. \& TREZEVANT, R. (2007). "Investor protection and the information content of annual earnings announcements: International evidence". Journal of Accounting and Economics, 43, 3767.

DESAI, M. A. (2005). "The degradation of reported corporate profits". Journal of Economic Perspectives, 171192.

FRANCIS, J. \& SCHIPPER, K. (1999). "Have financial statements lost their relevance?". Journal of accounting Research, 37, 319-352.

FRANK, W. G. (1979). "An empirical analysis of international accounting principles". Journal of Accounting Research, 17, 593-605.

GASSEN, J. (2008). Are stewardship and valuation usefulness compatible or alternative objectives of financial accounting?, Humboldt-Universität zu Berlin, Wirtschaftswissenschaftliche Fakultät.

GONCHAROV, I. \& ZIMMERMANN, J. (2007). "The supply of and demand for accounting information". Economics of Transition, 15, 257-283.

GOSHEN, Z. (2003). "The impact of insider trading rules on company law". Capital markets and company law, Oxford University Press, Oxford.

GOSHEN, Z. \& PARCHOMOVSKY, G. (2005). "The essential role of securities regulation". Duke LJ, 55, 711.

HUNG, M. \& SUBRAMANYAM, K. (2007). "Financial statement effects of adopting international accounting standards: the case of Germany". Review of accounting studies, 12, 623-657.

JACOBSON, R. \& AAKER, D. (1993). "Myopic management behavior with efficient, but imperfect, financial markets: A comparison of information asymmetries in the US and Japan". Journal of Accounting and Economics, 16, 383-405.

KOTHARI, S. (2001). "Capital markets research in accounting". Journal of accounting and economics, 31, 105231.

KOTHARI, S. \& SHANKEN, J. (2003). "Time-series coefficient variation in value-relevance regressions: a discussion of Core, Guay, and Van Buskirk and new evidence". Journal of Accounting and Economics, 34, 69-87.

LA PORTA, R., LOPEZ-DE-SILANES, F., SHLEIFER, A. \& VISHNY, R. (2000). "Investor protection and corporate governance". Journal of financial economics, 58, 3-27.

LA PORTA, R., LOPEZ-DE-SILANES, F., SHLEIFER, A. \& VISHNY, R. W. (1998). "Law and finance". Journal of Political Economy, 106, 1113-1155.

LA PORTA, R., LOPEZ- DE- SILANES, F., SHLEIFER, A. \& VISHNY, R. W. (1997). "Legal determinants of external finance". The journal of finance, 52, 1131-1150.

LANG, M., RAEDY, J. S. \& WILSON, W. (2006). "Earnings management and cross listing: Are reconciled earnings comparable to US earnings?". Journal of accounting and economics, 42, 255-283.

LEUZ, C., NANDA, D. \& WYSOCKI, P. D. (2003). "Earnings management and investor protection: an international comparison". Journal of financial economics, 69, 505-527.

LEV, B. (1983). "Some economic determinants of time-series properties of earnings". Journal of Accounting and Economics, 5, 31-48.

LEV, B. \& GU, F. (2016). The end of accounting and the path forward for investors and managers, John Wiley \& Sons.

LEV, B. \& ZAROWIN, P. (1999). "The boundaries of financial reporting and how to extend them". Journal of Accounting research, 37, 353-385.

LEVITT, A. (1998). "The importance of high quality accounting standards". Accounting horizons, 12, 79.

MERRYMAN, J. H. \& PÉREZ-PERDOMO, R. (2007). The civil law tradition: an introduction to the legal systems of Europe and Latin America, Stanford University Press.

NOBES, C. W. (1983). "A judgemental international classification of financial reporting practices". Journal of Business Finance \& Accounting, 10, 1-19. 
OEHR, T.-F. \& ZIMMERMANN, J. (2012). "Accounting and the welfare state: The missing link". Critical perspectives on accounting, 23, 134-152.

PIRVELI, E. (2014). "Accounting Quality in Georgia: Theoretical Overview and Development of Predictions". International Journal of Business and Social Science, 5, 283-293.

PIRVELI, E. (2015). Financial Statement Quality: First Evidence from the Georgian Stock Exchange, Shaker Verlag.

PIRVELI, E. \& ZIMMERMANN, J. (forthcoming). "Do Wealthy Economies Report Better Accounting Quality? International Evidence".

POPE, P. F. \& WALKER, M. (1999). "International differences in the timeliness, conservatism, and classification of earnings". Journal of accounting research, 37, 53-87.

SAUNDERS, A. \& THOMAS, H. (1997). Financial institutions management, Irwin Boston.

SCHOLES, M., BENSTON, G. J. \& SMITH, C. W. (1976). "A transactions cost approach to the theory of financial intermediation". The Journal of Finance, 31, 215-231.

SCHUMPETER, J. A. (1939). Business cycles, McGraw-Hill New York.

SHLEIFER, A. \& VISHNY, R. W. (1997). "A survey of corporate governance". The Journal of Finance, 52, 737783.

SMITH, A. \& MCCULlOCH, J. R. (1838). An Inquiry into the Nature and Causes of the Wealth of Nations, A. and C. Black and W. Tait.

SODERSTROM, N. S. \& SUN, K. J. (2007). "IFRS Adoption and Accounting Quality: A Review". European Accounting Review, 16, 675-702.

TEOH, S. H., WELCH, I. \& WONG, T. J. (1998a). "Earnings management and the long- run market performance of initial public offerings". The Journal of Finance, 53, 1935-1974.

TEOH, S. H., WELCH, I. \& WONG, T. J. (1998b). "Earnings management and the underperformance of seasoned equity offerings". Journal of Financial economics, 50, 63-99.

WATTS, R. L. \& ZIMMERMAN, J. L. (1978). "Towards a positive theory of the determination of accounting standards". Accounting review, 112-134.

WATTS, R. L. \& ZIMMERMAN, J. L. (1986). "Positive accounting theory".

WYATT, A. R. (1997). "International accounting standards and organizations: quo vadis?". International Accounting and Finance Handbook.

ZIMMERMANN, J. \& WERNER, J. R. (2013). Regulating Capitalism? The Evolution of Transnational Accounting Governance, Palgrave Macmillan. 